\title{
THE ASSOCIATIONS OF DURATION OF EXPOSURE AND TENURE WITH URINE HIPPURIC ACID LEVEL AMONG WORKERS AT PRINTING INDUSTRY IN MEDAN, NORTH SUMATERA
}

\author{
Mutiara Nauli, Taufik Ashar, Rahayu Lubis \\ Department of Environmental Health, Faculty of Public Health, \\ Universitas Sumatera Utara
}

\begin{abstract}
Background: Hippuric acid has been recognized for many decades as a constituent of the urine. In addition, hippuric acid in 24-hour urine collections is a potential biomarker for fruit and vegetable consumption. As previous studies have shown, fasting plasma hippuric acid significantly increased after a 12-week healthy diet enriched in bilberries, whole-grain products and fatty fish compared to a control group, while no changes occurred in a whole-grain enriched diet group. This study aimed to estimate the associations of duration of exposure and tenure with hippuric acid level among workers at printing industry in Medan, North Sumatera.

Subjects and Method: This was a cross sectional study conducted at printing industry in Medan, North Sumatera. A total of 16 workers were selected for this study. The dependent variable was urine hippuric acid level. The independent variables were duration of exposure and tenure. The correlations between urine hippuric acid and duration of exposure and tenure were measured by Pearson correlation coefficient ( $\mathrm{r}$ ).

Results: Urine hippuric acid level decreased with duration of exposure $(r=-0.25$; $\mathrm{p}=0.047)$ and tenure $(\mathrm{r}=-0.19 ; \mathrm{p}=0.002)$.

Conclusion: Urine hippuric acid level decreases with duration of exposure and tenure.

Keywords: urine hippuric acid, duration of exposure, tenure.

\section{Correspondence:}

Mutiara Nauli. Department of Environmental Health, Faculty of Public Health, Universitas Sumatera Utara, North Sumatera. Email: mutiara.nsrg@gmail.com. Mobile: 085211005549
\end{abstract}

